\title{
The Fragmentation of the Chinese Domestic Market
}

Peking struggles to put an end to regional protectionism

\section{Sandra Poncet}

\section{OpenEdition}

\section{Journals}

Édition électronique

URL : http://journals.openedition.org/chinaperspectives/410

DOI : $10.4000 /$ chinaperspectives. 410

ISSN : 1996-4617

Éditeur

Centre d'étude français sur la Chine contemporaine

Édition imprimée

Date de publication : 1 octobre 2004

ISSN : 2070-3449

\section{Référence électronique}

Sandra Poncet, «The Fragmentation of the Chinese Domestic Market », China Perspectives [En ligne], 55 | september - october 2004, mis en ligne le 24 juin 2008, consulté le 28 octobre 2019. URL : http:// journals.openedition.org/chinaperspectives/410 ; DOI : 10.4000/chinaperspectives.410

Ce document a été généré automatiquement le 28 octobre 2019.

(c) All rights reserved 


\title{
The Fragmentation of the Chinese Domestic Market
}

\author{
Peking struggles to put an end to regional protectionism
}

\section{Sandra Poncet}

\section{NOTE DE L'ÉDITEUR}

Translated from the French original by Peter Brown

1 The degree of integration of the Chinese domestic market has taken on particular importance since China's entry into the World Trade Organisation (WTO). Indeed, the opening up of the Chinese market to foreign companies can only be effective if free trade is guaranteed domestically. The preparedness of the central authorities to put an end to local protectionist measures has become apparent with the commitment to their WTO partners to ensure free access and free circulation of goods, services and capital. The fear of the Chinese leaders that domestic impediments are a source of friction with their partners would seem to explain the recent steps taken.

2 The idea of domestic economic integration was promoted at the third plenary session of the sixteenth central committee of the Chinese Communist Party (CCP), devoted to perfecting the socialist market economy, in October 2003 in Peking. Local protectionism appeared as one of the main concerns, while the leaders had the objective of taking the reform process further, providing for more balanced development and maintaining a sustained growth rate in order to absorb the workforce released by the restructurings from agriculture and state-owned enterprises.

3 A World Bank memorandum of October 2003 is of this view: "A domestic market that is flexible and integrated is vital for the development of Chinese competitiveness and growth, as well as for the structural adjustment of the Chinese economy. A free and integrated domestic market for goods and services, coupled with a free entry and exit for firms, allowing the most productive ones to grow and take advantage of economies of scale, facilitate the spread of technologies, and stimulate improvements in 
productivity that increase the competitiveness of firms and growth. (...) In the same way, the structural adjustment currently underway is all the more likely to produce sustainable, long-term results if it takes place within an integrated domestic market, one operating in accordance with the laws of the market place" ${ }^{\text {. }}$

The fragmentation of the Chinese economy in an increasingly globalised context is also problematic for maintaining macro-economic stability. A limited integration-or even one going backwards-of the Chinese provincial markets suggests a limited capacity on the part of provinces to absorb the asymmetrical shocks ${ }^{2}$. For some authors, significant discontinuities brought about by the provincial borders could even jeopardise national unity ${ }^{3}$.

5 This article ${ }^{4}$ analyses the degree of integration of the Chinese domestic market. First of all, it aims to identify the causes of local protectionism, before recounting the history of the commercial integration of the provinces over the course of the 1990s, based on intra-provincial exchange data. As Barry Naughton has shown ${ }^{5}$, examining interprovincial exchanges is the most direct way to study regional integration. This approach also enables an analysis of the importance of domestic trade in China in relation to international trade.

\section{A spinnery in Suzhou}

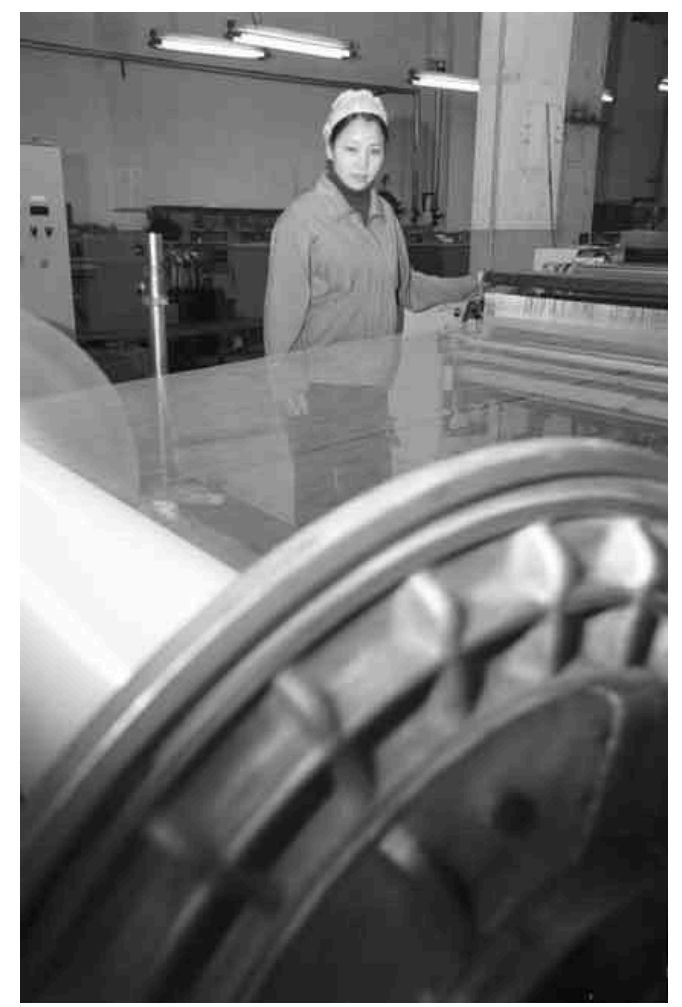

(c) Imaginechina

The rise of local protectionism in the late $1980 \mathrm{~s}$

Trade between provinces developed considerably after the launch of the reforms in the late 1970s. Ten years later, however, problems related to decentralisation and distortions in the pricing system were impediments to such exchanges. Andrew Wedeman has described these two stages in the development of local protectionism ${ }^{6}$. First, between 1987 and 1989, there were many inter-regional wars for the supply of 
resources. The regions producing raw materials blocked and even banned the export of scarce resources. The manufacturing regions, seeing their supply of essential inputs threatened, then launched counter-offensives, unleashing real clashes that were based in a multitude of products ranging from strategic inputs for industry (cotton, silk, tobacco, wool and tea), to foodstuffs (cereals, eggs, pork), and local spice specialities (mint oil, aniseed...)

7 The wool wars constituted a good example of this ${ }^{7}$. They broke out in the productive provinces, essentially in the north-west (Inner Mongolia, Gansu, Ningxia, Qinghai and Xinjiang). These provinces adopted a policy of "local production, use and sale" that required a limitation on exports to the rest of the country in order to satisfy the growing demand for local wool transformers. The introduction of production quotas was accompanied by export restrictions (concerning both tariffs and non-tariffs). The same logic was at the root of the silk wars that ensued in 1988 between Sichuan province, the main producer of cocoons, and the coastal provinces that were the users (Guangdong, Jiangsu and Zhejiang). The regions cultivating silk worms went so far as to deploy armed forces and militia on the borders to prevent the coastal provinces, which had the resources to offer better prices, from acquiring cotton. The rice war of 1988 between Guangdong province and the producing province of Hunan, or the cereal war between 1987 and 1989, that saw Fujian province pitted against producing provinces such as Hubei, Zhejiang, Jiangxi, Anhui and Henan, also illustrated the tensions born from the distortions in the pricing system and the divergence of interests between provinces.

A second form of regional protectionism appeared at the end of 1989, one that this time concerned imports from other provinces. Local governments, confronted with stockpiles and budgetary restrictions, due to the recession and the tight monetary policy of then Prime Minister Li Peng, restricted or outlawed the importation of many goods. At the time of the recession of late 1989, the manufacturing coastal provinces flooded the country with their unsold stock. Many inland provinces drew up lists of goods which were banned from being imported and set up "inspection posts" to collect taxes and fines. The restrictions mainly affected manufactured goods, particularly television sets, household appliances, bicycles, stereos or electrical equipment. Virtually all the provinces, even the most open ones like Guangdong or Peking, had recourse to protectionist measures. Thus, Peking limited imports of wood from Hebei province in 1992. Yet, these sorts of measures were especially adopted by the western provinces anxious to protect local production, such as Hubei, Shaanxi, Sichuan, Qinghai and most especially Xinjiang province.

Local governments implemented their protectionist policies through the use of all sorts of measures: road blocks, the seizing of merchandise, ad hoc taxes, administrative charges, biased technical standards, bureaucratic red tape ${ }^{8}$. Outside firms were confronted with enormous difficulties, whether for the purchase of premises, equipment or land, or for obtaining finance. They could become purely and simply victims of the theft of goods or of the vehicles being used to transport them. A prohibition on sales of certain imported goods was commonplace, parallel to the promotion of local production and its distribution through preferential financing arrangements.

The situation came to be of such concern that in November 1990, the State Council and the Central Committee of the CCP had to make repeated calls for the dismantling of the 
"vertical" and "horizontal" impediments to trade, for regional specialisation and the mobility of factors, advocated by the reforms.

The origins of protectionism

11 Local protectionism can be explained by two structural factors 9 . On the one hand, decentralisation, launched in 1980, gave added financial responsibility to the provinces without, however, providing them with more resources. On the other hand, the less developed regions pursued a policy of industrialisation through substitution for imports, in order to offer less money to the coastal provinces.

The generalisation of protectionism has been interpreted as a manifestation of serious shortcomings in the reform programme ${ }^{10}$. Distortions in pricing had existed well before 1978 (and were surely more widespread), but they were compensated for by the central government's budgetary redistribution policy. The latter taxed the industrialised regions and reallocated, via fiscal subsidies, a part of their profits to the provinces producing raw materials. Indeed, in spite of the increases in the purchase price of raw materials, particularly in the agricultural sector, the pricing system in the early days of the reforms gave a clear advantage to industry to the detriment of agriculture, thereby creating a "wedge factor between agricultural and industrial prices". The provinces producing raw materials (agricultural or energy sectors) lost out, suffering both from the depreciation of the prices of the goods that they sold and the high prices of the processed goods that they bought. On the other side, the provinces that specialised in light industry benefited twice over, in that they bought their inputs for a low cost and sold processed goods for a handsome profit. The extraction of a financial surplus in agriculture nationally to guarantee the financing of a rapid process of industrialisation had constituted a key element in the strategy of development prior to the reforms.

The system of compulsory delivery (tonggou) for strategic goods (cereals, energy...) maintained prices artificially low with respect to industrial goods. Farmers would never have accepted selling their produce to the state if a free market had been allowed ${ }^{11}$. Prior to 1978 and even until recently, agricultural produce was divided into three categories. The first included cereals, cotton, oilseed, and medicinal herbs. The second covered most of the inputs used by the food industry like meat, eggs, vegetables or fruit. The third category contained remaining agricultural produce, but unlike it, the first two were subject to a quota system, within which the state required that a part of the production be given up to it at a fixed, depreciated price. The irrationality of this pricing system induced a transfer of profits from the regions producing raw materials (in the centre and west of the country) towards the manufacturing provinces on the coast.

The reform of the fiscal system in 1980 put an end to the redistribution to the disadvantaged provinces; and the implementation of the policy of "separation of fiscal centres" amplified the feeling of injustice felt by the land-locked provinces. Decentralisation made each province responsible for the management of its expenditure based on its local revenues. As these came in large part from industrial profits, the provinces became very sensitive to the industry-agriculture relative prices. Whereas the coastal regions still benefited from the wedge effect of prices, the inland provinces that produced raw materials suffered from these distortions, without the central government being able to compensate them by reason of its lower returns.

15 The fiscally disadvantaged regions therefore used the new powers obtained through decentralisation to launch into policies of industrialisation and turned to protectionism 
to limit the imports of consumer goods from the coast and facilitate the development of infant industries sheltered from outside competition. As every jurisdiction was keen to develop its industrial base and keep its own resources, all types of industry were to be found in all of the provinces. This meant that factories making fridges, television sets and other household appliances existed practically everywhere, leading to major operations that were often less than optimal, and hence hardly competitive, especially in times of recession. The industrialisation of the provinces flew in the face of the principle of comparative advantage.

The central government was unable to manage the protectionist behaviour of the provinces, something that was magnified both by the centre's preferential policy and the actual motivations of provincial officials: "the provincial governments set up the policy of geben qiancheng (everyone runs their own race) or gexian shentong (everyone shows their particular achievements), which resulted in a situation of gezi weizheng (everyone acts consciously without regard for the general interest)"12. The absence of any co-ordination between the provincial governments not only brought about a duplication of activities, but also the implementation of local preferential policies and protectionist measures. Clashes between provinces with identical industrial structures became inevitable, as they struggled to get their inputs and gain markets.

Another source of protectionism-adding to the pricing distortions and the fiscal reform-lay in the flagrant bias of the policy of development in favour of the coastal regions. The central authorities gave priority in terms of investment to the coast and facilitated the rapid development of the east by allowing it to keep a greater part of its income in foreign currency and to create new financial instruments. This favouritism magnified the gap between the east and the west, by increasing the competitiveness of the coastal regions.

18 Disputes went hand in hand with the poorly controlled macro-economic fluctuations. At times of growth (1985-1988), the coastal industries massively bought the needed inputs, causing an increase in the price of raw materials such that the less efficient producers in the inland regions could no longer pay for their inputs. At the other extreme, during periods of recession (1989-1990), the country's interior saw itself being flooded with manufactured goods from the east. Inter-regional clashes for resources in times of expansion were thus followed by import restrictions in periods of recession.

The disputes were made possible by the absence of any legislation banning the interprovincial trade barriers. Several laws and regulations were adopted by the State Council between 1980 and 1990, but they were not given any priority status and figured in catch-all texts.

The protectionism of the provincial authorities with regard to goods from the rest of the country was part and parcel of the twin strategy of preserving socio-economic stability and maximising fiscal receipts. The barriers to inter-provincial trade had the goal of limiting the unfavourable social, economic and political consequences of the reforms (retrenchments, bankruptcies of local firms, declining profits) ${ }^{13}$. Local protectionism emerged as a strong fiscal autonomy of the local authorities and high unemployment, where the public sector provided the lion's share of job opportunities and where labour-intensive industries predominated.

Regional policies since the early 1990s Peking's response to regionalism 
The central leadership quickly took on board the danger represented by the centrifugal forces of regionalism and clearly criticised the policies of industrialisation through substitution for imports resulting in the proliferation of less than optimal firms ${ }^{14}$. As early as 1990, Li Peng and Zhou Jiahua, the President of the Planning Commission, pointed out the damage wrought by regional protectionism and announced urgent measures to fight against the chaos brought on by regionalism. In actual fact, however, the central authorities had to be content with verbal threats and changes in provincial leadership. It was forced to admit that the emergence of regionalisms, even if it put the country's unity in danger, was inseparable from the process of opening up and the reforms, the extension of which was vital for the political survival of the Party.

The few concrete steps taken by the central authorities to discourage protectionist practices did not manage to get the provincial authorities to see reason ${ }^{15}$. They were targeted at particular cases. Thus, following disputes over the supply of silk cocoons between Zhejiang and Jiangsu provinces, the Zhejiang provincial authorities were criticised, and forced to pay a fine and engage in self-criticism.

Artificially low fixed prices for cereals have hit agricultural regions hard

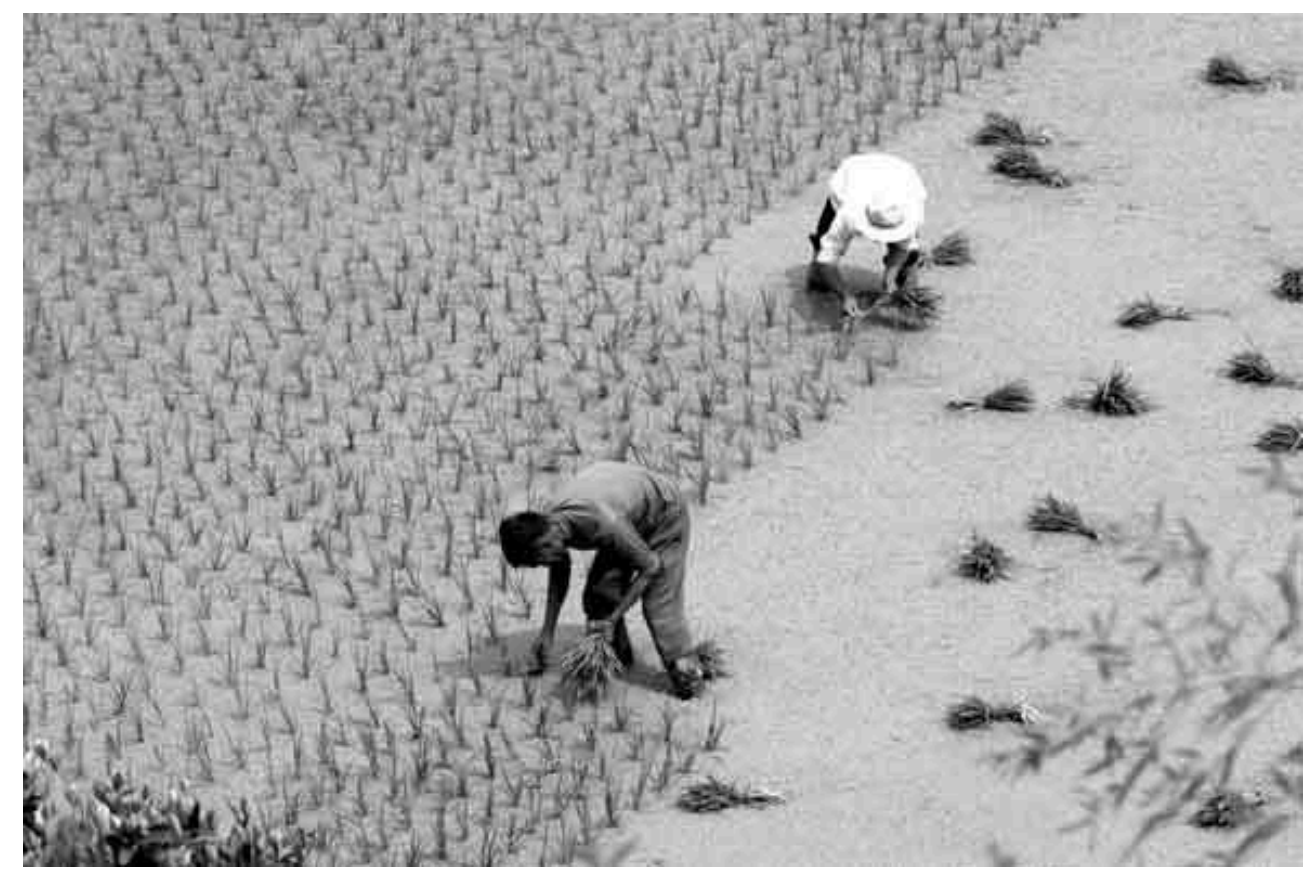

(c) Imaginechina

However, some developments enabled a partial response to be made to the primary causes of the disputes. The impatience of the inland provinces to benefit also from the reforms was finally heard at the start of the 1990s with the calling into question of the priority of coastal development and the model of spreading economic development on which the sixth and seventh five-year plans were based (1981-1985 and 1986-1990) ${ }^{16}$. The central authorities were keen to promote regional equity and hence to favour the development of the country's interior in step with that of the coast. The reform of the system of subsidising external trade, initiated in 1991, reduced the measures in favour of the special economic zones and the coastal cities. The subsidies were abolished and there was a harmonisation of the system of hard currency retention. This policy of 
more equal treatment of the various provinces favoured the take-off of trade directly managed by the inland provinces.

The eighth five-year plan (1991-1995) abandoned the tripartite (coast, centre and west) regionalisation of the seventh plan to draw up priorities in relation to sectors. In fact, it gave priority to agriculture and energy, areas in which the inland provinces specialised. The broadening of the reforms, particularly the decision adopted by the third plenary session of the Central Committee in November 1993 to promote a "balanced regional development", and the reduction in pricing distortions that had been unfavourable to the producers of raw materials, reduced the protectionist motivations of the provinces that had felt wronged.

The ninth five-year plan (1996-2000) continued on this path, by giving priority to the fight against regional disparities on the basis of significant investments in infrastructure, to co-operation between the coastal and inland provinces, and to the promotion of Foreign Direct Investment (FDI) and trade in the west of the country. Since the 1990s, the central authorities have made many calls for co-operation between the provinces and promoted the creation of multi-regional economic co-operation zones. The objectives have been, inter alia, the co-ordination of policies of regional development and the development of inter-border links. But it seems that in spite of the many co-operation zones thus created, the actual realisations have been few and far between, in the absence of any preparedness on the part of provincial governments to subsume their own short-term interests under the long-term ones of the region or the country as a whole.

The fiscal reform introduced at the beginning of 1994 enabled a recentralising of a part of the tax revenue and hence a strengthening of Peking's power. But it did not altogether eliminate the possibility for local governments to increase their revenue by taking action in terms of the volume of local sales. The new fiscal system did not sever the link between the government's income derived from taxation and the health of local firms. Thus, it was not a deterrent to protectionist measures since these were capable of safeguarding the tax base. Moreover, the reform of pricing is not complete yet, so local governments still have a tendency to favour investment in light processing industries, to the detriment of the logic of comparative advantage and of long-term national development.

The present situation

The inter-provincial economic "wars" of the kind that took place in the late 1980s have ceased, but the integration of the domestic market is still impeded on account of the twin role played by the local authorities, at once regulators and players in the field of economic activity. Not only do local governments own companies, but they also finance and regulate them, which means that they have complex and sometimes contradictory objectives. A firm's drive for profit in accordance with the laws of the marketplace goes hand in hand with the objective of maximising employment and growth, as well as local revenue derived from taxation. Local governments have control at once over production, distribution, taxation and subsidies... they are therefore in a position to turn to protectionist measures in order to provide for the development of their firms sheltered from external competition.

According to Barry Naughton ${ }^{17}$, several factors have reduced the interest in having recourse to protectionism. An improvement in the transport infrastructure, a reduction in the distortions of the pricing system, as well as a rebalancing of supply 
and demand for raw materials $s^{18}$ have weakened the incentive of local governments to intervene in the sphere of economic activity. Furthermore, interventionist policies have become more difficult with the increasing complexity of the economy. The multiplication of distribution networks has made government intervention less efficacious. Barry Naughton also states that the efforts of Prime Minister Zhu Rongji to reorganise and impose a severe budgetary constraint on the state banking system have weakened the strong connection that existed between the authorities and local banks. The stress placed by the central government on the necessary increase in budgetary revenue has made it more costly and more difficult to maintain the practice of supporting local firms through tax exemptions or hidden subsidies. Finally, interventions have become less necessary since the national policy of systematic defence of employment was abandoned in 1996. Yet, local protectionist policies have not disappeared ${ }^{19}$. The methods used include applying more rigorous procedures and technical and qualitative standards to imported goods than to local ones, granting local firms preferential access to the banking system and meting out biased treatment to outside firms when it comes to the settling of disputes through the courts. The international press reports regularly on protectionist practices ${ }^{20}$, a case in point being the support given by the municipal government to Shanghai Volkswagen, a joint venture of Volkswagen and the Shanghai Automotive Industrial Corp., whereby the company's Santana model was approved by the municipality as the car to constitute its fleet of taxis. At the same time, additional costs were imposed on licence plates and sales tax for cars from outside of Shanghai, which increased their final purchase price by an additional $10 \%$ on average. In Jiangxi province, supplementary taxes imposed by the provincial authorities amounted to $15 \%$. For Renault's Sanjiang model-produced by a joint venture between China Aerospace and Renault, based in Xiaogan in Hubei province-the surcharge amounted to 70,000 yuan (US\$8,500) per car and was the root cause of the withdrawal of the make from China in the late 1990 s.

While present efforts at restructuring (particularly the closing down of firms in the sectors having an overabundance of supply such as in the textile industry, coal-mining and beer manufacturing) are a step in the right direction towards integration, regional specialisation and a search for comparative advantage, their impact is for the time being difficult to quantify. Moreover, while the central government has been confirming its commitment to the rationalisation of production put in place at the end of the 1980s, the industrial policy of the ninth five-year plan made the blunder of favouring yet a further wave of duplication. Indeed, this plan identified a list of key industries characterised by a high-yield capacity, a strong technological content and a potential for spreading economic development. These were, in particular, transportation equipment (cars and motorbikes), electrical appliances, petrochemical goods, machines, metallurgy and construction materials. The central government encouraged the provinces to develop their own plans for investment and production based on local specificities and likely future returns. The logical upshot was the commitment of massive investment by the provinces in most of these sectors. The over-capacity and over-production of these goods brought about ferocious competition and a disastrous fall in prices, particularly for the provinces that had developed these sectors without any consideration for their comparative advantages. 
31 Local protectionism and the impediments to the economic unification of the domestic market remain current, as attested by the many declarations, regulations and studies on these subjects since 2000. At the annual session of the National People's Assembly (NPA) in March 2000, Wang Zhongfu, the Minister for Industry and Commerce, stated that the administrative monopolies, the imposed commercial contracts and the impediments to the market had become "a cancer in the Chinese market" ${ }^{21}$. In April 2001 , the State Council issued a directive outlawing regional barriers ${ }^{22}$.

Prohibitions announced by the State Council in April 2001

- Obliging companies or individuals to use only local goods and services.

- Imposing customs tariffs on roads, at railway stations, ports, airports and at borders to prevent the entry of external goods.

- Introducing differentiation in the pricing system.

- Applying differential techniques and criteria for evaluating external goods.

- Introducing discrimination in the allocation of entry permits for the local market.

- Adopting a discriminatory policy in the tender process or concerning the investments of outside companies.

Source : State Council No. 303 Order, Stipulation of the State Council to Forbid Regional Blockade in Market Economic Activities, 2001.

This 2001 regulation was published only in Chinese, without appearing in the Englishlanguage newspapers normally covering economic policy, a practice out of step with the reporting traditionally given to the other directives. This regulation contained 28 articles and had the aim of establishing a unified, equitable, normal market system, eliminating local protectionist measures and preserving the economic order of the socialist market economy. The above insert sets out the clearly formulated prohibitions and measures announced to deal with cases of abuse of these legal provisions concerning the suspension of functionaries and prison sentences.

A 2003 study of the break-up of the domestic market was carried out by the Development Research Centre of the State Council, involving academics, entrepreneurs and officials in order to assess the importance of impediments to economic activity in the various provinces ${ }^{23}$. The results clearly show the tobacco, alcoholic beverages and automobile sectors to be the worst affected by dint of their high profitability, strong tax base and monopolistic organisation. Among the main impediments denounced by the respondents are the job discrimination practices in favour of locals, the difficulties encountered by migrants in finding a school for their children, the local bias in the way disputes are dealt with by the courts, and the preferential treatment given to local firms in the public tendering process.

The increasing intensity of commercial activity between 1987 and 1997

While there have been many analyses of what curbs the process of national integration, whether these be natural or cultural impediments or political barriers set up by local governments, studies on the degree of integration of the Chinese domestic market have always run into the problem of the absence of data. Until now, researchers have had to be satisfied with data on transport and the sectorial structure of industrial production. Similarly, they have had to put up with aggregate pricing data or else attempt to make deductions based on trade data. Furthermore, most studies have had a limited impact where conclusions cannot really be generalised in so far as they are limited to a given region of China or a particular period of time. The objective of the final section of this 
article is to make up for this gap by examining the economic integration of the Chinese provinces based on trade data taken from the input-output (IO) tables drawn up by the provinces between 1987 and $1997^{24}$.

In each province, goods have three potential origins, namely local (or intra-provincial) production, the importation of goods produced in another province (inter-provincial importation) and international importation. The policy of reform was followed by a rapid increase in the rate of opening up to international trade as well as by the growth in imports. This increase in the imported proportion of consumer goods linked to a weakening of impediments to international trade implied a drop in one or both of the other two sources. In so far as the economic reforms have promoted the integration of the Chinese domestic market in tandem with the opening up internationally, one would expect imports to take the place of locally produced goods more than of supplies from elsewhere in the country. However, a statistical analysis of the data on the trade flows of the provinces between 1987 and 1997 does not confirm this hypothesis.

As Barry Naughton has pointed out, on the basis of the 1987 and 1992 data ${ }^{25}$, interprovincial exchanges are very important, whether measured relative to either GDP or to foreign trade. This gives the lie to the picture of a Chinese market made up of a juxtaposition of self-sufficient provinces such as that painted by Audrey Donnithorne in the early $1970 \mathrm{~s}^{26}$. The export and import rates in relation to the rest of the country amounted on average to $50 \%$ of the provincial GDP. In comparison, the average international export and import ratios of national GDP were $16 \%$ and $8 \%$ respectively over the period 1987-1997. Table 1 enables us to compare the participation in interprovincial and international trade for the coastal, central and western zones.

Chinese domestic trade appears to be proportionally higher than trade within Western Europe, NAFTA (North American Free Trade Agreement) or ASEAN (Association of Southeast Asian Nations). The intra-zone exchanges reached 18\% of the GDP of Western Europe in $1999,5.6 \%$ of the NAFTA GDP in 1998 , and $12 \%$ of ASEAN in $1998^{27}$. By way of comparison, the intra-China trade ratio as a percentage of GDP amounted to $38 \%$ on average in 1997. Inter-provincial exchanges were hence very important compared to international ones, which could undermine the view of self-sufficient Chinese provinces. Yet between 1992 and 1997, these exchanges were in decline, whereas intraprovincial exchanges progressed.

Between 1987 and 1997, the importance of inter-provincial exchanges showed a marked decline, whereas international exchanges experienced a rapid growth. While the average inter-provincial export rate was eight times higher than the average international export rate in 1987, in 1997 it was no more than 1.5. The same downward trend in the relation between inter-provincial and international trade can be seen for imports. A developing fragmentation of the Chinese domestic market, such as that suggested by Alwyn Young, would thus seem to be confirmed. ${ }^{28}$ While inter-provincial trade in China increased in value, it underwent a significant drop as a percentage of GDP between 1987 and 1997, in particular after 1992. Between 1987 and 1997, interprovincial trade increased less quickly than did the GDP, whereas the rates of international opening more than doubled. While inter-provincial exchanges went up overall in value by 5\% between 1987 and 1997, international imports and exports increased by $13 \%$ and $25 \%$ respectively. A larger part of provincial trade thus occurred with foreign partners. 
1. Movement of the opening up of domestic and international trade of the provinces

\begin{tabular}{|c|c|c|c|c|c|c|c|c|c|c|c|c|}
\hline \multirow[b]{2}{*}{ Year } & \multicolumn{3}{|c|}{$\begin{array}{l}\text { International } \\
\text { export rate }\end{array}$} & \multicolumn{3}{|c|}{$\begin{array}{l}\text { Inter-provincial } \\
\text { export rate }\end{array}$} & \multicolumn{3}{|c|}{$\begin{array}{l}\text { International } \\
\text { import rate }\end{array}$} & \multicolumn{3}{|c|}{$\begin{array}{l}\text { Inter-provincial } \\
\text { import rate }\end{array}$} \\
\hline & 1987 & 1992 & 1997 & 1987 & 1992 & 1997 & 1987 & 1992 & 1997 & 1987 & 1992 & 1997 \\
\hline Simple average & 10.3 & 13.8 & 22.8 & 46.7 & 44.9 & 33.0 & 3.5 & 9.2 & 15.1 & 53.7 & 48.9 & 38.1 \\
\hline Coast & 15.0 & 18.8 & 37.1 & 54.4 & 52.0 & 37.1 & 5.4 & 12.6 & 24.9 & 61.4 & 55.4 & 45.7 \\
\hline Inland & 5.5 & 7.7 & 5.5 & 44.3 & 45.2 & 31.2 & 1.2 & 4.7 & 2.7 & 48.8 & 50.1 & 32.5 \\
\hline West & 3.8 & 3.5 & 3.8 & 26.3 & 19.2 & 22.8 & 1.2 & 3.0 & 2.6 & 37.6 & 23.9 & 23.0 \\
\hline
\end{tabular}

Sources: IO tables and "China Statistical Yearbooks" published by the Chinese National Bureau of Statistics (Peking)

The main partner of the Chinese provinces in 1997 remained, however, the other provinces, although the situation was very uneven, both in terms of development and level. While the coastal provinces, especially during the 1990s, stood out through a rapid decline in the inter-provincial exchange ratio as a percentage of GDP, in line with a virtually symmetrical growth in their international exchanges, the other provinces experienced a less significant roll-back of their inter-provincial opening up and, in particular, did not benefit from any increase in their rates of opening up internationally. The coastal provinces appeared as the most integrated, not only with the rest of China, but also with the foreign market. In 1997, the average rate of international export by the coastal provinces caught up with the level of the interprovincial export rate at $37 \%$ of GDP. The inland provinces had less significant internal and international exchanges ( $30 \%$ and $5 \%$ respectively in 1997). The provinces in the west of the country put an end to the progress of integration, their international exchanges being quite minor (3\%) and their inter-provincial rate of opening up only half that of the coast (25\%).

The Chinese regions all have one common feature. This concerns the progressive roll back of the inter-provincial opening between 1987 and 1997. The question then is whether this corresponds to an effective reorientation of exchanges linked to internationalisation or whether, on the contrary, it may be interpreted as a movement of disintegration. The drop in internal trade within the coastal and interior zones happened mainly between 1992 and 1997, which would seem to be coherent with the chronology of the reforms and reflect their opening up to international exchanges, which increased in particular after 1992). The dynamic nature of inter-provincial exchanges was subject to dual forces. First, all economic liberalisation should have favoured exchanges between provinces, in comparison with the era of planned exchanges and the policy of self-sufficiency. Next, the policy of international opening up (no longer restricted to the coast, but stepped up and broadened to the provinces as a whole) should have led to an intensification of relations with the outside world that seems to have worked to the detriment of internal (intra- and inter-provincial) trade. A phenomenon of substitution between international and inter-provincial trade certainly seems to have taken hold, particularly since 1992. The predominance of interprovincial over international trade thus appears to be quite relative and above all temporary. The policy of opening up to world trade by the Chinese provinces is something recent following several decades of a virtually totally closed shop and hence of necessary internal supply. The rebalancing of exchanges is therefore only in its infancy. The Chinese provinces are still heavily protected from the world market, as 
confirmed by the difficult negotiations on China's entry into the WTO. It will only really be possible to reach a conclusion about the importance of inter-provincial exchanges relative to international exchanges, and hence about the real commercial integration of the Chinese provinces, once there is a broader liberalisation of international exchanges.

Moreover, the view of China as a set of cellular provinces can be excluded only by comparing the part of locally consumed production with that of the production exchanged with the other provinces. Setting inter-provincial trade on the same footing as international trade is not enough. We must compare the scope and development of inter-provincial exchanges with those of intra-provincial ones. Table 2 provides the breakdown of absorption between the three potential sources of goods: international, inter-provincial and intra-provincial. A province's absorption are calculated as the sum of production and imports minus exports. The total imports and exports include trade with the rest of China and internationally. Logically, the inland and western provinces appear to be the most self-sufficient, with $80 \%$ of their expenses going on local goods, as against around $20 \%$ on products from other parts of the country and a small portion for foreign goods. Conversely, the coastal provinces appear to be the most outwardlooking both with regard to the rest of the country and international markets.

Concerning developments over time, a drop in the inter-provincial trade can be observed for the period 1987-1997, in line with an increase in intra-provincial and international trade for the three groups of provinces. Differences appear nonetheless between these groups for the sub-periods 1987-1992 and 1992-1997. In the western provinces, the decline in the share of inter-provincial consumer goods mainly occurred prior to 1992, no doubt in relation to the trade disputes-their being replaced by local goods. Subsequently, one can notice a relative stabilisation between 1992 and 1997, at a very low level, around $17 \%-19 \%$. In the coastal provinces, the drop in the share of goods from the rest of the country was also significant prior to 1992, but it continued, by reason this time of the effect of substitution of international imports: the fall back from $27.7 \%$ to $22.1 \%$ of the share of domestic goods corresponded to an increase from $6.3 \%$ to $12.1 \%$ of the share of foreign goods, without any change in the share of local goods. In the inland provinces, the drop in the inter-provincial supply also occurred under the twin effect of substitution of international and local goods. It would appear that these provinces, faced with the rapid take-off of the coast, were engaged throughout the 1990s in the active promotion of substitution industries for imports sheltered from competition with the rest of the country in order to develop their economy and support employment and the survival of loss-making public enterprises ${ }^{29}$.

\section{Movement in the composition of provincial absorption}

\begin{tabular}{|c|c|c|c|c|c|c|c|c|c|}
\hline \multirow[b]{2}{*}{ Year } & \multicolumn{3}{|c|}{ Local goods } & \multicolumn{3}{|c|}{ Rest of China } & \multicolumn{3}{|c|}{ International } \\
\hline & 1987 & 1992 & 1997 & 1987 & 1992 & 1997 & 1987 & 1992 & 1997 \\
\hline Simple average & 64.3 & 68.0 & 71.0 & 33.5 & 27.0 & 20.8 & 22 & 5.1 & 8.2 \\
\hline Coast & 60.8 & 66.0 & 65.8 & 36.1 & 27.7 & 22.1 & 3.2 & 6.3 & 12.1 \\
\hline Inland & 67.1 & 66.4 & 80.5 & 32.1 & 30.7 & 18.0 & 0.8 & 2.8 & 1.5 \\
\hline West & 72,8 & 80.5 & 78.1 & 26.3 & 17.3 & 19.6 & 0.8 & 2.2 & 2.3 \\
\hline
\end{tabular}

Sources: IO tables and "China Statistical Yearbooks" published by the Chinese National Bureau of Statistics (Peking) 
efore appears that the drop in intensity of inter-provincial trade is due both to internationalisation and the development of intra-provincial exchanges (greater selfsufficiency of the provinces). This leads one to have doubts about any real integration of the domestic market. Indeed, the promotion of the process of internal opening up by the reforms in parallel with the international opening up was motivated by the search for both static and dynamic gains. These had to result from the intensification of competition, the spread of technological progress and the productive specialisation as a function of comparative advantage.

Prior to the reforms, the policies of inward-looking development led to inefficient and non-competitive production that completely overlooked the questions of comparative advantage, economies of scale and productive specialisation. In this sense, at a provincial level, it is logical that with the opening up to world trade, imported goods be substituted both for locally produced ones (intra-provincial trade) and for goods from other provinces (inter-provincial trade). It can even be expected that substitution will occur more to the detriment of local goods than of goods imported from the other provinces. Indeed, the liberalisation of the economy should promote competition between the provinces. The reduction in the share of national goods to the benefit of local production in the absorption of the Chinese provinces, on consumption, between 1987 and 1997, ran counter to the logic, promoted by the reforms, of regional specialisation in terms of comparative advantage and economies of scale. Concerns about the growing fragmentation of the domestic market cannot but increase.

\section{NOTES}

1. World Bank, China: Promoting growth with equity, Country Economic Memorandum, The World Bank Group, Washington DC, 2003, p. 23.

2. An asymmetrical shock is a shock in the supply and demand, local or general, the effects of which are differentiated or specific to each region.

3. This problem is tackled for example in M. H. Chang, "China's Future: Regionalism, Federation, or Disintegration" Studies in Comparative Communism, Vol. 25 (3), September 1992, pp. 211-227. Refer also to Alwyn Young, "The Razor's Edge: Distortions and Incremental Reform in the People's Republic of China", Quarterly Journal of Economics, Vol. 115, No. 4, November 2001, pp. 1091-1135, and David S. G. Goodman and Gerald Segal (ed.), China Deconstructs: Politics, Trade and Regionalism, London, New York, Routledge, 1994.

4. We take up here some of the findings of our doctoral thesis: "Intégration ou fragmentation interne de l'économie chinoise" [Integration or Internal Fragmentation of the Chinese Economy], economics Ph.D. thesis, prepared and defended in the Centre d'Etudes et de Recherches sur le Développement International (CERDI) [Centre for Studies and Research on International Development], University of Auvergne, 2003. 
5. Barry Naughton, "How much can regional integration do to unify China's markets?", in Nicholas Hope, Dennis Yang and Mu Yang Li (ed.), How far across the river? Chinese Policy Reform at the Millennium, Stanford, Stanford University Press, 2003, pp. 204-232. 6. Chinese Economic Studies, special edition on local protectionism in China, Vol. 26, No. $5,1993$.

7. Zhang Xinohe, Lu Weiguo, Sun Keliang, Christopher Findlay and Andrew Watson, "The Wool War and the Cotton Chaos: Fibre Marketing in China", in Ross Garnaut, Guo Shutian and Ma Guonan (ed.), The Third Revolution in the Chinese Countryside, Cambridge and New York, Cambridge University Press, 1996.

8. Guo Rongxing, Border Regional Economics, Heidelberg, Physica-Verlag, 1996.

9. Pak K. Lee, "Local Economic Protectionism in China's Economic Reform", Development Policy Review, Vol. 16, 1998, pp. 281-303.

10. See Chinese Economic Studies, Vol. 26, No. 5, 1993.

11. Yuk-shing Cheng and Shu-ki Tsang, "The changing grain marketing system in China", The China Quarterly, 140, 1994, pp. 1081-1104.

12. Anjali Kumar, "China's Reform, Internal Trade and Marketing”, The Pacific Review, Vol. 7, No. 3, 1994, pp. 323-339.

13. Sandra Poncet, "Fragmented China. Measure and Determinants of Chinese Domestic Market Disintegration", Review of International Economics, forthcoming.

14. See Dali L.Yang, Beyond China, liberalisation and the regions, Routledge, 1997, and Chinese Economic Studies, op. cit., for the list of government decrees.

15. Shaun Breslin, "Decentralisation, Globalisation and the 'creation' of Trans-National Economic Regions in the People's Republic of China", CSGR Working Paper 38/99, University of Warwick, 1999.

16. The logic of that model was to privilege the eastern coast, with growth spreading over time to the neighbouring provinces and hence gradually to the country as a whole. This model of a gradual spread stems from the ladder-step theory or trickle down theory.

17. Barry Naughton, "How much can regional integration do to unify China's markets?", op. cit.

18. Abandoning the policies of development centred on the intensive sectors in the area of raw materials as well as the promotion of the energy and agricultural sectors enabled there to be a reduction in demand and an increase in the supply of production inputs.

19. Institute of Industrial Economics, Zhongguo gongye fazhan baogao (China's Industrial Development Report), Peking, Jingji guanli chubanshe, 1998.

20. See, inter alia, Bruce Gilley, "Breaking Barriers", Far Eastern Economic Review, July 12th 2001, or Trish Helliwell, "China's City Limits", Far Eastern Economic Review, October 14th 1999. Refer also to "Chinese Walls", Forbes Global, December 11th 2001.

21. People's Daily, July 1 st 2000.

22. State Council No. 303 Order, Stipulation of the State Council to Forbid Regional Blockade in Market Economic Activities, 2001.

23. Li Shantong, Liu Yunzhong, Chen Bo, "Research on measures objects and degrees on local protection in the Chinese domestic market-An analysis based on a sample survey", Development Research Centre of the State Council, Peking 2003.

24. The data on inter-provincial flows are scarce and hard to obtain. The values of "exports" and "imports" between the provinces are calculated thanks to the inflowsoutgoings (IO) tables that Chinese provinces are supposed to draw up every five years. These tables, in existence for at least 1987, 1992 and 1997, are not published. The data 
have been obtained for 28 provinces in 1987 (Qinghai province and Tibet are missing), 27 provinces in 1992 (Inner Mongolia, Hainan province and Tibet are missing), and 28 provinces in 1997 (Hainan province and Tibet are missing). For further details, see Sandra Poncet, "Measuring Chinese domestic and international integration", China Economic Review, Vol. XIV, No. 1, pp. 1-21.

25. Barry Naughton, "How much can regional integration do to unify China's markets?", op. cit.

26. Audrey Donnithorne, “China's Cellular Economy: Some Trends since the Cultural Revolution”, China Quarterly, LII, pp. 605-619.

27. Intra-zone trade corresponds to the value of exchanges made between members of the association related to the zone's total GDP (sum of the GDP of the member countries). Sources: EU-EUROSTAT/COMEXT and COMTRADE - IMF.

28. Alwyn Young, "The Razor's Edge", op. cit.

29. Refer to Cécile Batisse and Sandra Poncet, "Protectionism and Industry localization in Chinese Provinces", Journal of Chinese Economic and Business Studies, Vol. 2 (2), 2004, pp. 133-154. The authors show that the impediments to exchanges not only influence the locating of activities, but also and especially that their impact became greater between 1992 and 1997.

\section{RÉSUMÉS}

This article analyses the degree of integration of the Chinese domestic market. It recounts the stages in the development of regional protectionist practices from the late 1980s, and describes the present situation and the efforts of the central authorities to bring these practices to an end. It also presents the main structural factors that account for regional protectionism. Finally, the work studies the economic integration of the Chinese provinces based on trade data taken from input-output (IO) tables drawn up by the provinces between 1987 and 1997. It makes clear the drop in the intensity of inter-provincial trade, under the twin pressures of internationalisation and the development of intra-provincial exchanges. This movement, which corresponds to a greater self-sufficiency of the provinces, runs counter to the logic of regional specialisation promoted by the reforms, in terms of comparative advantage and economies of scale.

\section{INDEX}

Thèmes : economie 